\title{
A Critical Analysis of the Value Chain in the Rice Industry and Its Effects on the Export Rice Industry in Kien Giang Province, Vietnam
}

\author{
Van Ngoc Bach ${ }^{1}$, Cuong Hung Pham ${ }^{2} \&$ Nhan Hoang Vo ${ }^{3}$ \\ ${ }^{1}$ Kien Giang Import Export Co., Ltd, Vietnam \\ ${ }^{2}$ Foreign Trade University, Ho Chi Minh City Campus, Vietnam \\ ${ }^{3}$ University of Medicine Pham Ngoc Thach, Vietnam \\ Correspondence: Nhan Hoang Vo, University of Medicine Pham Ngoc Thach, \#86/2 Thanh Thai, District 10, Ho Chi \\ Minh City, Vietnam.
}

Received: April 9, 2016

Accepted: May 4, 2016

Online Published: May 13, 2016

doi:10.5430/ijfr.v7n3p1

URL: http://dx.doi.org/10.5430/ijfr.v7n3p1

\begin{abstract}
The study of a critical analysis of the value chain in the rice industry and its effects on the export rice industry in Kien Giang province, Vietnam conducted during the period from December 2012 to November2015. The research result showed that there were 450 persons who are rice exporters and farmers (412 processed and 48 missed) who to be interviewed and answered nearly 27 questions. The researcher had analyzed KMO test, the result of KMO analysis used for multiple regression analysis. The person responses measured through an adapted questionnaire on a 5-point Likert scale. Hard copy and interviewrice exporters and farmersby questionnaire distributed among rice exporters and farmers in KienGiang province.

The regression analysis results showed that there were seven factors, which included of factors following: Development strategy; Control policy; Planning; Support policy; Rice seeds;Cultivation techniques andPost-harvest processingactually affected the export rice industry with $5 \%$ significance level. The main objectives of this study were to to conduct a survey to find value chain that affecting the export rice industry in KienGiang province, to identify value chain that affected on the export rice industry in KienGiang province and to analyze and to test value chain that affected the export rice industry in KienGiang province.
\end{abstract}

Keywords: Value chain, rice industry, effects, export rice industry, Kien Giang Province

\section{Introduction}

Agriculture plays a relatively important role in the economy of Vietnam. Agriculture contributes $24 \%$ of GDP and generates $20 \%$ of export revenues. Over $70 \%$ of the national labor force is employed in the agriculture sector, and a further $6 \%$ is employed in the agricultural postproduction sector. Vietnam exported some 7.5 million tons of rice in 2014 via both official and cross-border export transactions, said Vietnam Industry and Trade Center (VITIC) under the Ministry of Industry and Trade (MoIT) on Tuesday. According to VITIC, via official exports, Vietnam sold some 6.5 million tons of rice to world market, pocketing 2.84 billion U.S. dollars in 2014. The average export price of Vietnamese rice in 2014 was 436.92 U.S. dollars per ton. The year 2014 posted the third consecutive year when China has remained the largest consumer of Vietnamese rice, while importing 2.1 million tons of rice from Vietnam via official exports. The Philippines ranks the second, consuming 1.4 million tons of rice from Vietnam in 2014.

In addition to official exports, Vietnam sold around one million tons of rice to China via cross-border transactions in 2014, bringing total figure of Vietnamese rice export volume last year to 7.5 million tons, said VITIC.VITIC quoted a report by Vietnam Food Association as saying that in 2015, the country targeted to export 7-7.5 million tons of rice. Currently, Vietnamese rice has been present in 135 countries and regions worldwide, according to Import and Export Department under the MoIT. The price of rice for exports from Vietnam, the world's second largest rice exporter, in the international market has risen substantially in the first two months of this year, amid soaring rice exports, according to the country's food association. In the last two months, the price of Vietnam's rice has remained steady at US\$245 to US\$260 per ton, up US\$55 per ton from the same period last year, said Truong ThanhPhong, chairman of Vietnam Food Association (Vietfood), the country's rice export managing body. Rice prices will continue to stand at that height in the near future as demand is increasing. "The price won't fall because demand is very strong, and 
also because farmers are facing high production costs for fertilizer and gasoline," Phong said. Despite the start of the harvest season in the Mekong Delta region, high global demand continues to push prices of exportable rice higher in the local market. Most of Vietnam's rice for export is grown in the Mekong Delta region.

\section{Literature Review}

Often multinational enterprises (MNEs) developed global value chains, investing abroad and establishing affiliates that provided critical support to remaining activities at home. To enhance efficiency and to optimize profits, multinational enterprises locate "research, development, design, assembly, production of parts, marketing and branding" activities in different countries around the globe. MNEs offshore labor-intensive activities to China and Mexico, for example, where the cost of labor is the lowest (Gurría, 2012).The emergence of global value chains (GVCs) in the late 1990s provided a catalyst for accelerated change in the landscape of international investment and trade, with major, far-reaching consequences on governments as well as enterprises. (Gurría 2012)

Through global value chains, there has been growth in interconnectedness as MNEs play an increasingly larger role in the internationalization of business. In response, governments have cut corporate income tax (CIT) rates or introduced new incentives for research and development to compete in this changing geopolitical landscape. (LeBlanc et al). In an (industrial) development context, the concepts of Global Value Chain analysis were first introduced in the 1990s (Gereffi et al.) and have gradually been integrated into development policy by the World Bank, Unctad, the OECD and others. Value chain analysis has also been employed in the development sector as a means of identifying poverty reduction strategies by upgrading along the value chain. Although commonly associated with export-oriented trade, development practitioners have begun to highlight the importance of developing national and intra-regional chains in addition to international ones.

The value-chain concept has been extended beyond individual firms. It can apply to whole supply chains and distribution networks. The delivery of a mix of products and services to the end customer will mobilize different economic factors, each managing its own value chain. The industry wide synchronized interactions of those local value chains create an extended value chain, sometimes global in extent. Porter terms this larger interconnected system of value chains the "value system". A value system includes the value chains of a firm's supplier (and their suppliers all the way back), the firm itself, the firm distribution channels, and the firm's buyers (and presumably extended to the buyers of their products, and so on).

The agricultural value chain. It concept has been used since the beginning of the millennium, primarily by those working in agricultural development in developing countries. Although there is no universally accepted definition of the term, it normally refers to the whole range of goods and services necessary for an agricultural product to move from the farm to the final customer or consumer.The term value chain was first popularized in a book published in 1985 by Michael Porter, who used it to illustrate how companies could achieve what he called "competitive advantage" by adding value within their organization. Subsequently the term was adopted for agricultural development purposes and has now become very much in vogue among those working in this field, with an increasing number of bilateral and multilateral aid organizations using it to guide their development interventions.

The Rice Value Chain. The Bill \& Melinda Gates Foundation are focusing on rice as a key crop in their fight to improve nutrition and increase smallholder farmer incomes. TechnoServe worked with the Gates Foundation to analyze the rice sector throughout India and Bangladesh, providing detailed studies of the rice value chains in selected states and identifying potential regions, partners and intervention models for future interventions on a large scale across India and Bangladesh. Besides, the rice value chain analysis was undertaken at the request of International Fund for Agriculture Development and Community Based Agriculture \& Rural Development Project. The analysislooked how rice was produced, processed and ultimately marketed to the consumers. Theobjective was to see how the value chain could be enhanced for the primary benefit of thesmallholder producers.

The analysis indicted the value chain was similar to the value chain of most commoditiesproduced and marketed domestically in financially suppressed economies common to thedeveloping world including Nigeria. That is the value chain was dominated by a multitude ofsmall family enterprises, each vying for a limited market share. This includes the smallholderproducers as family enterprises. The value chain could be conveniently divided betweenproduction which is mostly the farmers and support services, processing which is a combinationof parboiling and milling, and marketing which is mostly bulk through the open air markets.

Enhancing the value chain for the benefit of the smallholder producers should start at theproduction end where the smallholder farmers have the most direct involvement. Here the initialneed is to increase the rice area allocated to 
each farmer, so the farmers will concentrate on riceproduction as their primary farm enterprise. With the present small allocations farmers have littleincentive to concentrate on rice cultivation.

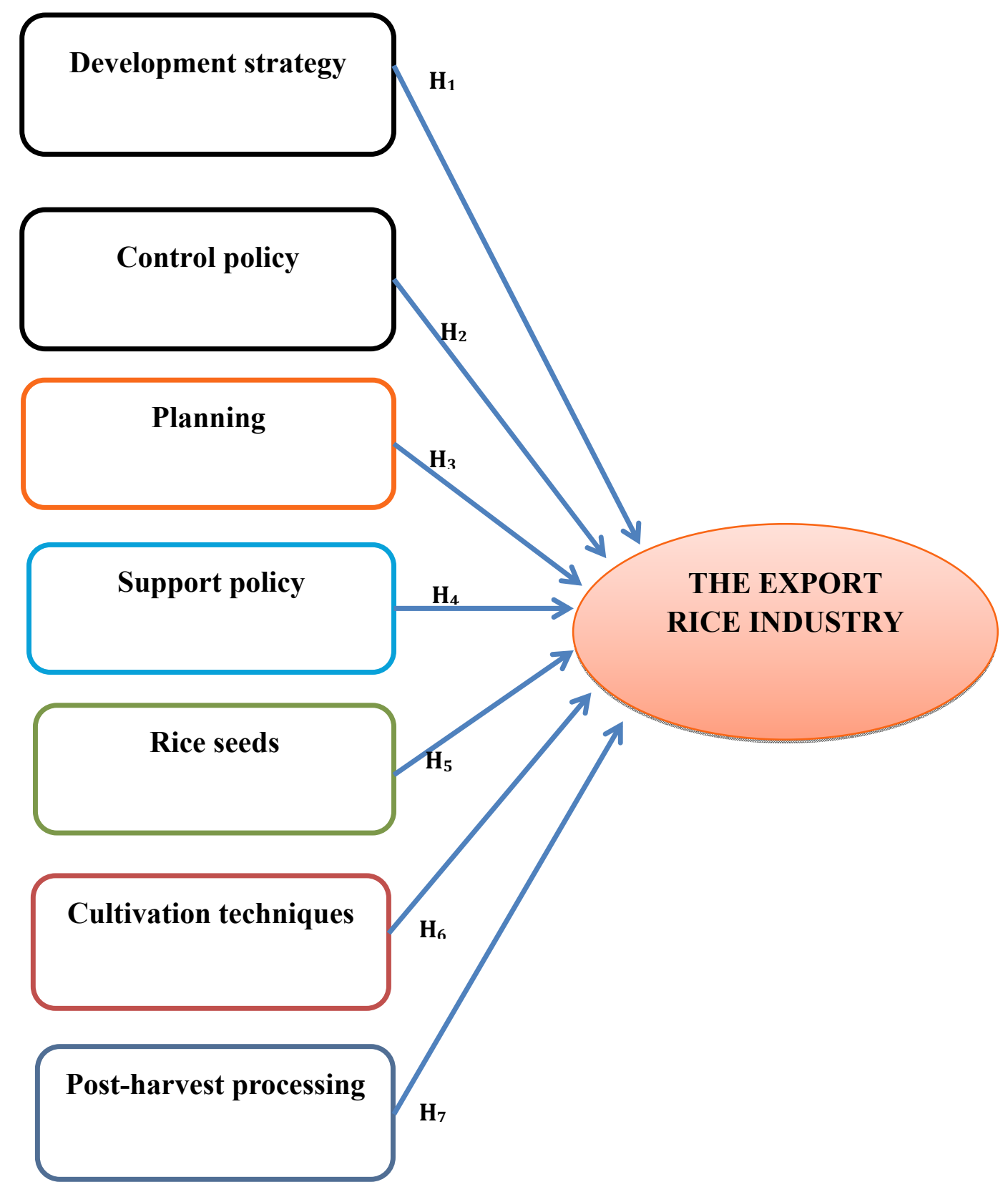

Figure 2. Proposed research model for the export rice industry

Based on the aforementioned research questions the following hypotheses used to investigate each question:

\section{Hypothesis}

$\mathbf{H}_{1}$ : There is a positive relationship between Development strategyand the export rice industry.

$\mathbf{H}_{2}$ : There is a positive relationship between Control policyand the export rice industry.

$\mathbf{H}_{3}$ : There is a positive relationship between Planningand the export rice industry.

$\mathbf{H}_{4}$ : There is a positive relationship between Support policyand the export rice industry.

$\mathbf{H}_{5}$ : There is a positive relationship between Rice seeds and the export rice industry. 
$\mathbf{H}_{6}$ : There is a positive relationship between Cultivation techniquesand the export rice industry.

$\mathbf{H}_{7}$ : There is a positive relationship between Post-harvest processing and the export rice industry.

\section{Research Method}

This study has not been fully considered all factors that influence sustainability. This dissertation focuses on considering the impacts of components. The researcher had surveyed 150 exporters and 300 farmers (450 persons who are rice exporters and farmers in KienGiang province). In this study, there are consists of two phases: First: it is a preliminary study and the second phase is a formal and more comprehensive study. This study is done by qualitative methods. The research is done by formal quantitative methods. Unit of analysis is a student. Study subjects are persons who are rice exporters and farmers in KienGiang province.

The preliminary study for exporters and farmersconducted in 10/2014, using qualitative methods to interview 30 persons who are rice exporters in KienGiang province to examine the content and meaning of the words used in the scale. Following this, the formal study conducted in May 2014, using qualitative methods to interview 450 persons who are rice exporters and farmers in KienGiang province. The researcher should select one of these methods of collecting the data taking into consideration the nature of investigation, objective and scope of the inquiry, financial resources, available time and the desired degree of accuracy.However, I should pay attention to all these factors but much depends upon the ability and experience of the researcher.

The population of this study was all 350 exporters and 3000 farmers in KienGiang province. The values of the random variable of interest could possibly be determined. This notion corresponds directly to the frame in sample survey literature. The difference between the attributes of interest in the study population and the corresponding attributes in the target population called the study error. This is a simple quantitative assessment for numerical attributes but can be challenging to define for graphical ones. The study population and the study units were very different from the target in this instance. The statistical method ensures consideration of the relevance of the study population to the target population by forcing investigators to deal directly with the study error. Criteria beyond the study error such as cost, convenience, and ethics is important in determining the study population.

After preliminary investigations, formal research done by using quantitative methods questionnaire survey of 150 exporters and 300 farmers ( 450 persons who are rice exporters and farmers in KienGiang province). The reason tested measurement models, model and test research hypotheses. Data collected were tested by the reliability index (excluding variables with correlation coefficients lower $<0.30$ and variable coefficient Cronbach's alpha $<0.60$ ), factor analysis explored (remove the variable low load factor $<0.50$ ). The hypothesis tested through multiple regression analysis with linear Enter method. The subjects of this survey are exporters and farmers and sample size 450 persons. The survey will be done by surveying exporters and farmers who have been treatment in KienGiang province. Now, Kien Giang provinceAdministrative divisions: Kien Giang is divided into one city (Rach Gia), one town (Ha Tien), and 13 districts (Kien Luong, Hon Dat, Tan Hiep, Chau Thanh, Giong Rieng, Go Quao, An Bien, An Minh, Vinh Thuan, Phu Quoc, Kien Hai, U Minh Thuong, Giang Thanh).

\section{Research Results}

The researcher collected 150 exporters and 300 farmers (450 persons who are rice exporters and farmers in KienGiang province) to analyze multiple regressions. Data from questionnaires analyzed using the descriptive statistics with the help of data analysis software - Statistical Package for Social Sciences (SPSS 20.0) package. We can see the demographic characteristics of the exporters and farmers table 1 following.

Table 1. Descriptive Statistics for the demographic characteristics of the exporters and farmers

\begin{tabular}{llcc}
\hline \multicolumn{2}{c}{ The demographic characteristics of exporters and farmers } & Frequency & Percentage \\
\hline \multirow{3}{*}{ Exporters and farmers } & Exporters & 150 & 36.4 \\
\cline { 2 - 4 } & Farmers & 262 & 63.6 \\
\cline { 2 - 4 } & Total & 412 & 100 \\
\hline \multirow{3}{*}{ Gender } & Male & 148 & 35.9 \\
\cline { 2 - 4 } & Female & 264 & 64.1 \\
\cline { 2 - 4 } & Total & 412 & 100.0 \\
\hline
\end{tabular}




\begin{tabular}{llcc}
\hline \multirow{4}{*}{ Age } & Under 20 years old & 26 & 6.3 \\
\cline { 2 - 4 } & From 20 to 40 years old & 90 & 21.8 \\
\cline { 2 - 4 } & Over 40 years old & 296 & 71.8 \\
\cline { 2 - 4 } Family situation & Total & 412 & 100.0 \\
\hline \multirow{4}{*}{ Experiences } & Single & 142 & 34.5 \\
\cline { 2 - 4 } & Married & 270 & 65.5 \\
\cline { 2 - 4 } & Total & 412 & 100.0 \\
\hline \multirow{4}{*}{ Income } & Under 5 years & 46 & 11.2 \\
\cline { 2 - 4 } & From 5 to 10 years & 289 & 70.1 \\
\cline { 2 - 4 } & More than 10 years & 71 & 18.7 \\
\cline { 2 - 4 } & Total & 39 & 100.0 \\
\hline & Under 5 million VND & 323 & 78.5 \\
\cline { 2 - 4 } & From 5 to 10 million VND & 412 & 100.0 \\
\cline { 2 - 4 } & More than 10 million VND & & 12.1 \\
\cline { 2 - 4 } & Total & 40.5 & \\
\hline
\end{tabular}

Source: The researcher's collecting data and SPSS

The Table 1 revealed that the result of the descriptive statistics from the demography following: we had 150 exporters and 300 farmers interviewed but 412 persons who are rice exporters and farmers in KienGiang province processed. 148people are male with $35.9 \%$, female with $64.1 \%$. For persons interviewed, the age accounted for the largest percentage is over 40 years old accounting for $71.8 \%$, followed by from 20 years oldto 40 years old accounting for $21.8 \%$.For persons interviewed, the family situation accounted for the marriedpersonsaccounting for $65.5 \%$ followed the second the singlepersons accounting for $34.5 \%$.Experiences: persons had experiences from 5 to 10 years with $70.1 \%$. Finally, Income: Table 1 showed 412 persons processed, 323 persons'income are from 5 to 10 million VNDwith 78.4\%.

Table 2. Questions for the value chain affecting the export rice industry

\section{Development strategy (DS)}

\section{Level of Agreement}

DS1: Development of rice into a commodity industry, with prestigious brands

(1) (2) (3) (4) (5)

DS2: Economic restructuring and labor structure along with the process of industrialization and modernization

(1) (2) (3) (4) (5)

DS3: Identify farmers and businesses are key actors of rice production and create

linkages between farmers and benefit businesses

(1) (2) (3) (4) (5)

DS4: Rice Development towards quality and sustainability

(1) (2) (3) (4) (5)

2. Control policy

Level of Agreement

CP1: State study change control approach for food safety to conform with the Law on Food Safety in accordance with international practice

CP2: Compliance with WTO commitments

(1) (2) (3) (4) (5)

(1) (2) (3) (4) (5)

CP3: Increase the competitiveness of enterprises in the process of integration, reduced costs are incurred for business

(1) (2) (3) (4) (5) 
PL1: State planning is closely rice, maximize comparative advantages and resources of each province, each locality

(1) (2) (3) (4) (5)

PL2: The Government should build the safe production of raw materials on a large scale and advanced technology as standard VietGap and international standard

PL3: State planning system enterprises exporting rice processing industry planning of rice processing

PL4: Application of modern processing technology to produce qualified products that meet the demanding markets

\section{Support policy (SP)}

Level of Agreement

SP1: The Government and relevant ministries need support policies as policies on preferential credit support to enterprises and farmers to grow rice

(1) (2) (3) (4) (5)

SP2: Policies to encourage scientific research activities to create rice varieties with high yield and good quality

SP3: Policies to attract foreign investment in order to boost investment process in depth

\section{Rice seeds (RS)}

Level of Agreement

RS1: Element manage quality rice varieties

(1) (2) (3) (4) (5)

RS2: Tight control element for rice disease

(1) (2) (3) (4) (5)

RS3: Elements of plant protection products for rice

(1) (2) (3) (4) (5)

\section{Cultivation techniques (CT)}

Level of Agreement

CT1: Investment factor for modern production technology

(1) (2) (3) (4) (5)

CT2: Building organizational models and associated manufacturing production consumes large scale

(1) (2) (3) (4) (5)

CT3: Cultivation techniques for producer knowledge level

(1) (2) (3) (4) (5)

\section{Post-harvest processing (PH)}

Level of Agreement

PH1: Capital investment for postharvest processing

(1) (2) (3) (4) (5)

PH2: Capital investment and technical factors harvesting technology

(1) (2) (3) (4) (5)

PH3: Capital investment element of highly qualified labor for processing

8. General assessment of export rice industry (GA)

(1) (2) (3) (4) (5)

GA1: Profits of exporters rose

Level of Agreement

GA2: farmers increase income

(1) (2) (3) (4) (5)

GA 3: Value added over 1 hectare of land to increase rice exports

(1) (2) (3) (4) (5)

Source: The researcher's collecting data and SPSS

Table 2 showed there were 26 questions for the value chain affecting the export rice industry. 26 questions following: Development strategy (DS) has 4 items, Control policy (CP) has 3 items, Planning (PL) has 4 items, Support policy (SP)has 3 items, Rice seeds (RS) has 3 items, Cultivation techniques (CT) has 3 items and Post-harvest processing $(\mathrm{PH})$ has 3 items. The export rice industry has 3 items. We used scales 5 five score following: 1: Strongly disagree; 2 : Disagree; 3: Normal; 4: Agree and 5: Strongly agree. 
The researcher used descriptive and summary statistics has an extensive history and, indeed, the simple tabulation of populations and of economic data was the first way the topic of statistics appeared. More recently, a collection of summarization techniques has been formulated under the heading of exploratory data analysis: an example of such a technique is the box plot.Descriptive statistics is the discipline of quantitatively describing the main features of a collection of information, or the quantitative description itself. Descriptive statistics are distinguished from inferential statistics (or inductive statistics), in that descriptive statistics aim to summarize a sample, rather than use the data to learn about the population that the sample of data is thought to represent. This generally means that descriptive statistics, unlike inferential statistics, are not developed on the basis of probability theory. Even when a data analysis draws its main conclusions using inferential statistics, descriptive statistics are generally also presented the following of Table 3.

Table 3. Descriptive statistics for the export rice industry

\begin{tabular}{cccccc}
\hline Code & $\mathrm{N}$ & Minimum & Maximum & Mean & Std. Deviation \\
\hline DS1 & 412 & 2.00 & 5.00 & 3.9442 & .96372 \\
DS2 & 412 & 1.00 & 5.00 & 3.3544 & 1.10546 \\
DS3 & 412 & 2.00 & 5.00 & 3.6092 & 1.30513 \\
DS4 & 412 & 1.00 & 5.00 & 3.2985 & 1.35650 \\
CP1 & 412 & 1.00 & 5.00 & 3.5388 & 1.09008 \\
CP2 & 412 & 1.00 & 5.00 & 3.5631 & 1.08894 \\
CP3 & 412 & 1.00 & 5.00 & 3.5437 & 1.09879 \\
PL1 & 412 & 1.00 & 5.00 & 3.1529 & .92198 \\
PL2 & 412 & 1.00 & 5.00 & 3.2816 & .98324 \\
PL3 & 412 & 1.00 & 5.00 & 3.3471 & .90600 \\
PL4 & 412 & 1.00 & 5.00 & 3.2621 & .93028 \\
SP1 & 412 & 1.00 & 5.00 & 2.9345 & .86459 \\
SP2 & 412 & 1.00 & 5.00 & 2.8325 & 1.58110 \\
SP3 & 412 & 1.00 & 5.00 & 2.8325 & 1.45780 \\
RS1 & 412 & 1.00 & 5.00 & 2.9029 & .86020 \\
RS2 & 412 & 1.00 & 5.00 & 2.9029 & .72514 \\
RS3 & 412 & 1.00 & 5.00 & 2.9296 & .74638 \\
CT1 & 412 & 1.00 & 5.00 & 3.3155 & 1.01926 \\
CT2 & 412 & 1.00 & 5.00 & 3.3641 & .91936 \\
CT3 & 412 & 1.00 & 5.00 & 3.0583 & .94186 \\
PH1 & 412 & 1.00 & 5.00 & 2.8981 & 1.38967 \\
PH2 & 412 & 1.00 & 5.00 & 3.0437 & .97063 \\
PH3 & 412 & 1.00 & 5.00 & 3.1990 & 1.24951 \\
GA1 & 412 & 2.00 & 5.00 & 3.3204 & .65756 \\
GA2 & 412 & 2.00 & 5.00 & 3.2306 & .74005 \\
GA3 & 412 & 2.00 & 5.00 & 3.3617 & .68191 \\
Valid N & 412 & & & & \\
\hline
\end{tabular}

Source: The researcher's collecting data and SPSS

Table 3 showed that there were 412 persons who are rice exporters and farmers in KienGiang province. Theyinterviewed and processed from 10/2014 to 6/2015. The results showed that max value is 5 , minimum is 1 , mean is around 3.0 and Std. Deviation is around 1.0.

Table 4. Results of analysis of Cronbach Alpha coefficients

\begin{tabular}{cllll}
\hline Indicators & $\begin{array}{l}\text { Average scale if } \\
\text { removal } \\
\text { variables }\end{array}$ & $\begin{array}{l}\text { Scale variance if } \\
\text { the removal } \\
\text { variables }\end{array}$ & $\begin{array}{l}\text { The } \\
\text { correlation } \\
\text { coefficient of } \\
\text { the total } \\
\text { variations }\end{array}$ & $\begin{array}{l}\text { Cronbach alpha } \\
\text { coefficient if the } \\
\text { removal variables }\end{array}$ \\
\hline
\end{tabular}




\begin{tabular}{|c|c|c|c|c|c|}
\hline \multirow{4}{*}{$\begin{array}{l}\text { Development } \\
\text { strategy (DS) }\end{array}$} & DS1 & 10.2621 & 11.736 & .865 & .891 \\
\hline & DS2 & 10.8519 & 11.528 & .750 & .918 \\
\hline & DS3 & 10.5971 & 9.755 & .849 & .886 \\
\hline & DS4 & 10.9078 & 9.432 & .853 & .887 \\
\hline \multicolumn{6}{|l|}{ Alpha $=0.920$} \\
\hline \multirow{3}{*}{$\begin{array}{l}\text { Control policy } \\
\text { (CP) }\end{array}$} & CP1 & 7.1068 & 4.704 & .976 & .982 \\
\hline & $\mathrm{CP} 2$ & 7.0825 & 4.704 & .978 & .981 \\
\hline & $\mathrm{CP} 3$ & 7.1019 & 4.681 & .971 & .986 \\
\hline \multicolumn{6}{|l|}{ Alpha $=0.989$} \\
\hline \multirow{4}{*}{ Planning (PL) } & PL1 & 9.8908 & 6.068 & .740 & .844 \\
\hline & PL2 & 9.7621 & 5.724 & .763 & .835 \\
\hline & PL3 & 9.6966 & 6.188 & .726 & .850 \\
\hline & PL4 & 9.7816 & 6.084 & .726 & .850 \\
\hline \multicolumn{6}{|l|}{ Alpha $=0.879$} \\
\hline \multirow{3}{*}{$\begin{array}{l}\text { Support policy } \\
\text { (SP) }\end{array}$} & SP1 & 5.6650 & 8.184 & .594 & .870 \\
\hline & SP2 & 5.7670 & 4.077 & .829 & .591 \\
\hline & SP3 & 5.7670 & 4.982 & .732 & .696 \\
\hline \multicolumn{6}{|l|}{ Alpha $=0.821$} \\
\hline \multirow{3}{*}{ Rice seeds (RS) } & RS1 & 5.8325 & 2.115 & .590 & .976 \\
\hline & RS2 & 5.8325 & 2.028 & .861 & .721 \\
\hline & RS3 & 5.8058 & 2.011 & .833 & .741 \\
\hline \multicolumn{6}{|l|}{ Alpha $=0.869$} \\
\hline Indicators & & $\begin{array}{l}\text { Average scale if } \\
\text { removal } \\
\text { variables }\end{array}$ & $\begin{array}{l}\text { Scale variance if } \\
\text { the removal } \\
\text { variables }\end{array}$ & $\begin{array}{l}\text { The } \\
\text { correlation } \\
\text { coefficient of } \\
\text { the total } \\
\text { variations }\end{array}$ & $\begin{array}{l}\text { Cronbach alpha } \\
\text { coefficient if the } \\
\text { removal } \\
\text { variables }\end{array}$ \\
\hline \multirow{3}{*}{$\begin{array}{c}\text { Cultivation techniques } \\
\text { (CT) }\end{array}$} & CT1 & 6.4223 & 2.429 & .769 & .574 \\
\hline & $\mathrm{CT} 2$ & 6.3738 & 2.945 & .672 & .692 \\
\hline & CT3 & 6.6796 & 3.308 & .501 & .861 \\
\hline \multicolumn{6}{|l|}{ Alpha $=0.797$} \\
\hline \multirow{3}{*}{$\begin{array}{c}\text { Post-harvest } \\
\text { processing (PH) }\end{array}$} & PH1 & 6.2427 & 4.379 & .571 & .857 \\
\hline & $\mathrm{PH} 2$ & 6.0971 & 5.188 & .792 & .654 \\
\hline & PH3 & 5.9417 & 4.498 & .674 & .722 \\
\hline \multicolumn{6}{|l|}{ Alpha $=0.809$} \\
\hline \multirow{3}{*}{$\begin{array}{c}\text { General assessment of } \\
\text { export rice (GA) }\end{array}$} & GA1 & 6.5922 & 1.595 & .454 & .730 \\
\hline & GA2 & 6.6820 & 1.234 & .607 & .546 \\
\hline & GA3 & 6.5510 & 1.396 & .570 & .596 \\
\hline
\end{tabular}

Alpha $=0.720$

Source: The researcher's collecting data and SPSS 
The Table 4 revealed that all Development strategy; Control policy; Planning; Support policy; Rice seeds; Cultivation techniques and Post-harvest processing $(26$ items) are very good for this research. The researcher continuesto analyze the EFA to assess more accurately the scale, helping the uniform scale in research. Thus, based on EFA analysis, the researcher will evaluate the homogeneity of the observed variables and can be classified because of specific variables. Besides, Cronbach alpha coefficient if the removal variables is more than 0.6. In addition, the correlation coefficient of the total variations is more than 0.3 .

KMO \& Bartlett's Test of Sphericity is a measure of sampling adequacy that recommended checking the case to variable ratio for the analysis conducted. In most academic and business studies, KMO \& Bartlett's test play an important role for accepting the sample adequacy. While the KMO ranges from 0 to 1, For Factor Analysis recommended suitable, the Bartlett's Test of Sphericity must be less than 0.05 .

Table 5. KMO and Bartlett's Test for the value chainaffecting the export rice industry

\begin{tabular}{cccccccc}
\hline Com. & \multicolumn{5}{c}{ Initial Eigenvalues } & Extraction Sums of Squared Loadings & $\begin{array}{c}\text { Rotation Sums of } \\
\text { Squared } \\
\text { Loadings }\end{array}$ \\
\cline { 2 - 7 } & Total & $\begin{array}{c}\text { \% of } \\
\text { Variance }\end{array}$ & Cumulative \% & Total & $\begin{array}{c}\text { \% of } \\
\text { Variance }\end{array}$ & $\begin{array}{c}\text { Cumulative } \\
\text { \% }\end{array}$ & Total \\
\hline 1 & 4.984 & 21.668 & 21.668 & 4.984 & 21.668 & 21.668 & 3.905 \\
2 & 4.496 & 19.547 & 41.215 & 4.496 & 19.547 & 41.215 & 3.508 \\
3 & 2.484 & 10.802 & 52.016 & 2.484 & 10.802 & 52.016 & 3.851 \\
4 & 2.170 & 9.436 & 61.452 & 2.170 & 9.436 & 61.452 & 3.183 \\
5 & 2.127 & 9.248 & 70.700 & 2.127 & 9.248 & 70.700 & 2.619 \\
6 & 1.244 & 5.408 & 76.109 & 1.244 & 5.408 & 76.109 & 3.173 \\
7 & 1.080 & 4.695 & 80.804 & 1.080 & 4.695 & 80.804 & \\
8 & .708 & 3.080 & 83.884 & & & & \\
9 & .553 & 2.406 & 86.290 & & & & \\
10 & .505 & 2.197 & 88.488 & & & & \\
11 & .457 & 1.988 & 90.476 & & & & \\
12 & .383 & 1.664 & 92.140 & & & & \\
13 & .336 & 1.461 & 93.600 & & & & \\
14 & .295 & 1.282 & 94.882 & & & & \\
15 & .269 & 1.168 & 96.050 & & & & \\
16 & .213 & .927 & 96.977 & & & & \\
17 & .184 & .801 & 97.778 & & & & \\
18 & .166 & .721 & 98.499 & & & & \\
19 & .140 & .611 & 99.110 & & & & \\
20 & .102 & .442 & 99.552 & & & & \\
21 & .041 & .180 & 99.731 & & & & \\
22 & .035 & .154 & 99.885 & & & & \\
23 & .026 & .115 & 100.000 & & & & \\
\hline
\end{tabular}

Source: The researcher's collecting data and SPSS

Table 5 showed that Kaiser-Meyer-Olkin Measure of Sampling Adequacy was statistically significantandhigh datareliability $(\mathrm{KMO}=0.763>0.6)$. This result was very good for data analysis. Table 5 showed that Cumulative percent was statistically significantandhigh datareliabilitywas $80.804 \%(>60 \%)$. This is very good Data for next research.

Table 6. Structure Matrix for the value chain affecting the export rice industry

\begin{tabular}{cccccccc}
\hline Code & \multicolumn{7}{c}{ Component } \\
\cline { 2 - 8 } & 1 & 2 & 3 & 4 & 5 & 6 & 7 \\
\hline DS1 & .971 & & & & & &
\end{tabular}




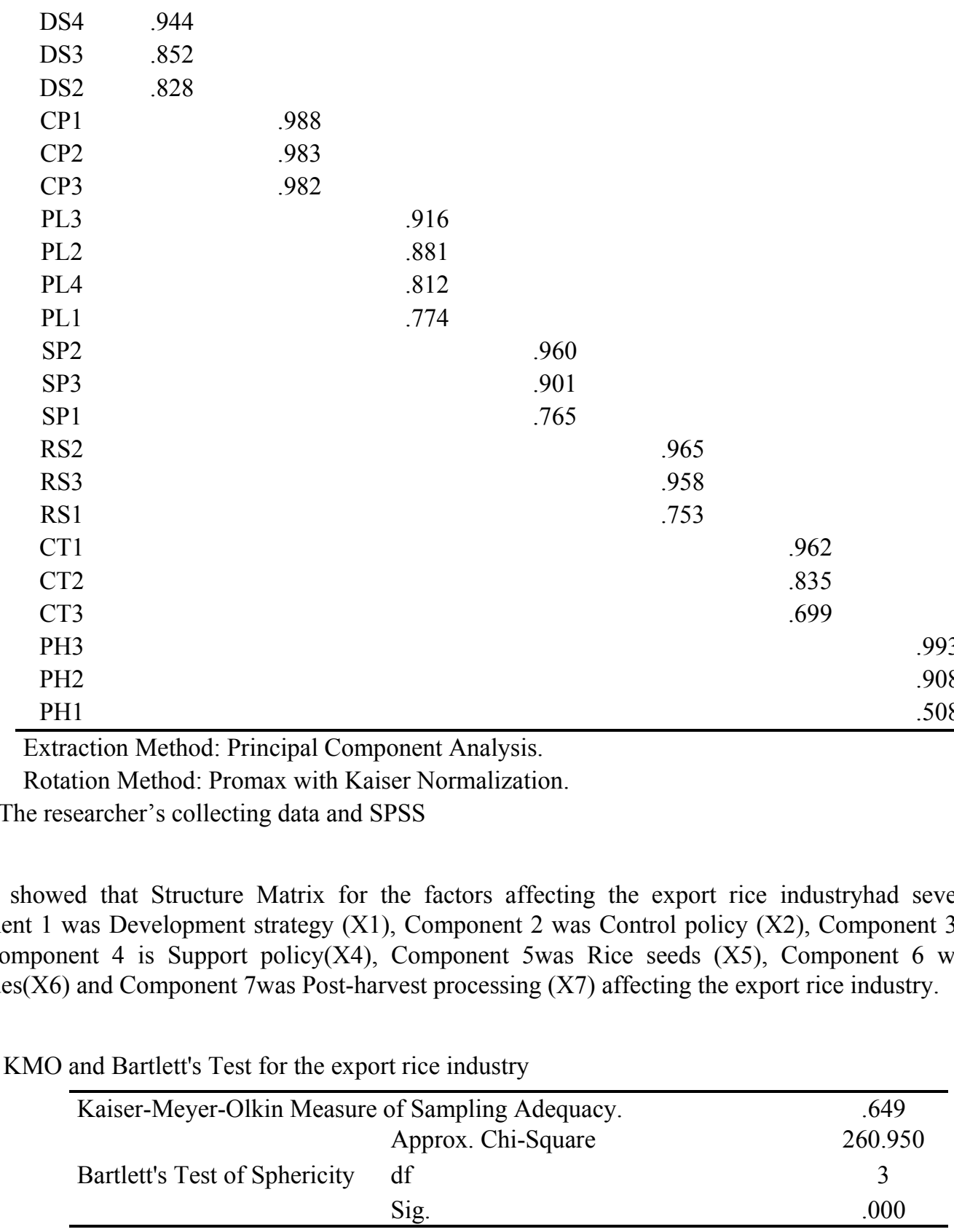

Source: The researcher's collecting data and SPSS

Table 6 showed the Component 1 was Development strategy (X1), Component 2 was Control policy (X2), Component 3 was Planning (X3), Component 4 is Support policy(X4), Component 5was Rice seeds (X5), Component 6 was Cultivation techniques(X6) and Component 7was Post-harvest processing (X7) affecting the export rice industry.

Table 7. KMO and Bartlett's Test for the export rice industry

Table 7 showed that KMO and Bartlett's Test for the sustainabilityshowed that Kaiser-Meyer-Olkin Measure of Sampling Adequacy was statistically significantandhigh datareliability $(\mathrm{KMO}=0.649>0.6)$.

Table 8. Total variance explainedfor the export rice industry

\begin{tabular}{ccccccc}
\hline Component & \multicolumn{3}{c}{ Initial Eigenvalues } & \multicolumn{2}{c}{ Extraction Sums of Squared Loadings } \\
\cline { 2 - 6 } & Total & $\begin{array}{c}\text { \% of } \\
\text { Variance }\end{array}$ & Cumulative \% & Total & \% of Variance & Cumulative \% \\
\hline 1 & 1.926 & 64.198 & 64.198 & 1.926 & 64.198 & 64.198 \\
2 & .655 & 21.846 & 86.044 & & & \\
3 & .419 & 13.956 & 100.000 & & & \\
\hline
\end{tabular}

Source: The researcher's collecting data and SPSS 
Table 8 showed that the result was very good for data analysis. The export rice industryshowed that cumulative percent was statistically significantandhigh datareliabilitywas $63.198 \%$ (> $60 \%)$. Extraction Method: Principal Component Analysis.Rotation Method: Promax with Kaiser Normalization.Total variance explained for the export rice industry is $63.198 \%$. Besides, total of Initial Eigenvalues is $1.926>1$.

\section{Conclusion}

This study investigated how the export rice industry could be measured following: First of allDevelopment strategy (X1) affecting on the export rice industrywith significance level of five percent. The secondly, the Control policy (X2) affecting on the export rice industrywith significance level of five percent. Thirdly, the Planning (X3) affecting on the export rice industrywith significance level of five percent.Fourthly, the Support policy (X4) affecting on the export rice industrywith significance level of five percent.Fifthly, the Rice seeds (X5) affecting on the export rice industrywith significance level of five percent.Sixthly, the Cultivation techniques (X6) affecting on the export rice industry with significance level of five percent. Finally, the Post-harvest processing (X7) affecting on the export rice industry with significance level of five percent.

Although rice productivity of KienGiang province is high, with yields averaging 5.3 tonnes per hectare, there are significant differences between regions. In some areas of the KienGiang province, we have some farmers achieving up to 10-12 tonnes per hectare.

Rice plays an important role in the export earnings of the KienGiang province. Among the agricultural products, the rice is one of the commodity, which is exported to many countries in the world and contributing considerable share in the export earnings of total agricultural products. The KienGiang province had export earnings realized from the export of the rice during the last years.

The results of data analysis revealed that respondents consider the followingfactors as the most influential factors:

1. Planning; standardized coefficients of beta is 0.352 .

2. Support policy; standardized coefficients of beta is 0.346 .

3. Development strategy; standardized coefficients of beta is 0.339 .

4. Post-harvest processing;standardized coefficients of beta is 0.253 .

5. Cultivation techniques;standardized coefficients of beta is 0.203 .

6. Rice seeds; standardized coefficients of beta is 0.154 .

7. Control policy; standardized coefficients of beta is 0.089 .

The results of data analysis revealed that all sevencomponents of the most influential factors related to the export rice industrywith significance level of $5 \%$. This result confirmed what found in the Planningthat was the most important factor to the export rice industry.

The results of data analysis revealed that all sevencomponents of the most influential factors related to the export rice industry with significance level of $5 \%$. This result confirmed what found the Control policythat was the less important factor to the export rice industry.

\section{References}

Agro Infor. (2009). Vietnam Annual Rice Market Report 2008. Information Center for Agriculture and RuralDevelopment. Institute of Policies and Strategies for Agriculture and Rural Development, Hanoi.

Ary, D., Jacobs, L., Sorensen, C., \& Razavieh, A. (2009). Introduction to research ineducation (8th ed.). Belmont, CA: Wadworth.

Balat, J., Brambilla, I., \& Porto, G. (2009). Realizing the Gains from Trade: Export Crops, Marketing Costs, and Poverty. Journal of International Economics.

Becket, N., \& Brookes, M. (2006). Evaluating quality management in university departments. Quality Assurance in Education.

Berg, B. (2001). Qualitative research methods for the social sciences. Boston:Allyn and Bacon.

Bernstein, W. (2008). A Splendid Exchange: How Trade Shaped the World. New York: Grove Press.

Coxhead, I., Linh, V. H., \& Tam, L. D. (2012). Global Market Shocks and Poverty in Vietnam: The Case of Rice. DEPOCEN Working Paper No. 2012/32. Development and Policies Research Center, Hanoi. 
Creswell, J. (2003). Research Design: Qualitative, Quantitative, and Mixed Methods Approaches. Thousand Oaks, California: Sage Publications.

Dawson, S., \& Dargie, C. (2002). New Public Management: a discussion with special reference tothe UK. In K. McLaughlin, S.P. Osborne, \& E. Ferlie (Eds.), New Public Management: Current trends and future prospects. London: Routledge.

De Silva D.A.M. (2011). Value chain of fish and fishery products: origin, functions and application in developed and developing country markets. Food and Agriculture Organization.

Feller, A., Shunk, D., \& Callarman, T. (2006). Value Chains Versus Supply Chains. BPTrends.

Ganeshan, R., \& Harrison, T. P. (1995). An Introduction to Supply Chain Management. Department of Management Sciences and Information Systems, 303 Beam Business Building, Penn State University, University of Park.

Georges Giraud. (2013). The World Market of Fragrant Rice, Main Issues and Perspectives. International Food and Agribusiness Management Review.

Howell, K. E. (2013). Introduction to the Philosophy of Methodology. London: Sage Publications.

Hunter, D. J. (2005). The National Health Service 1980-2005. Editorial. Public Money \&Management.

Joshi, Rakesh Mohan. (2005). International Marketing. Oxford University Press, New Delhi and New York.

Kaplinsky, R. (2000). Spreading the gains from globalisation: what can be learned from value market chain analysis?. IDS Working, Institute of Development Studies, University of Sussex, Brighton, UK.

Levesque. (2007). SPSS Programming and Data Management: A Guide for SPSS and SAS Users. SPSS Inc., Chicago.

Linh H. Vu. (2011). Efficiency of Rice Farming Households in Vietnam: A DEA with Bootstrap and Stochastic Frontier Application. Department of Applied Economics, University of Minnesota.

Lowe, M., \& Gereffi, G. (2009). A Value Chain Analysis of the U.S. Beef and Dairy Industries. Center on Globalization, Governance \& Competitiveness, Duke University.

Ministry of Agriculture and Rural Development. (2006 - 2012). General Report of export and import in the field of agriculture and rural development, Hanoi.

Moore, D., George, P., \& McCabe, B. C. (2012). Introduction to the practice of statistics. New York: W.H. Freeman. New York: Harcourt, Brace.

Ngo, S., \& Chan, S. (2010). Agriculture Sector Financing and Services for Smallholder Farmers. Phnom Penh: The NGOForum on Cambodia.

Probability, econometrics and truth. (2000). The methodology of econometrics. By Hugo A. Keuzenkamp Published by Cambridge University Press, ISBN.

Phélinas, P. M. (2001). Sustainability of Rice Production in Thailand. Hauppauge, New York: Nova Science Publishers, Inc.

Silverman, D. (Ed). (2011). Qualitative Research: Issues of Theory, Method and Practice. Thousand Oaks, New Delhi, Singapore: Sage Publications.

Sirirat Kiatpathomchai. (2008). Assessing Economic and Environmental Efficiency of Rice Production Systems in Southern Thailand: An Application of Data Envelopment Analysis. International Journal of Business and Management Invention.

Suzanne K. Redfern. (2012). Rice in Southeast Asia: facing risks and vulnerabilities to respond to climate change. International Rice Research Institute.

Thath Rido. (2014). Factors Affecting Cost Efficiency of Cambodian Rice Farming Households. Forum of International Development Studies.

Tran, T. C., Do, H. L., \& Le, M. N. (2013). Who Has Benefited From High Rice Prices in Vietnam? Oxfam International, Hanoi.

Watkins, A. E., Richard, L., S., \& George, W. C. (2008). Statistics in action: understanding a world of data. Emeryville, CA: Key Curriculum Press. 